\title{
9: $123853443-123874996$
}

National Cancer Institute

\section{Source}

National Cancer Institute. 9: 123853443-123874996. NCI Thesaurus. Code C45143.

Physical location of LHX2_Gene 